\title{
Adaptation against Myth: Gary Owen's Iphigenia in Splott and the Violence of Austerity
}

\begin{abstract}
Author:
Rebeca Gualberto

Universidad Complutense de Madrid, Spain rgualberto@ucm.es

https://orcid.org/0000-0002-1474-1577

Date of reception: $02 / 02 / 2021$

Date of acceptance: 14/06/202

Citation:

Gualberto, Rebeca. 2021. "Adaptation against

Myth: Gary Owen's Iphigenia in Splott and the

Violence of Austerity." Alicante Journal of English Studies 35: 119-140.

https://doi.org/10.14198/raei.2021.35.06

(C) 2021 Rebeca Gualberto

Licence: This work is licensed under a Creative Commons Attribution 4.0 International License (CC BY 4.0).

\section{(C) (1)}

\section{Rebeca GuALBERTO}

\begin{abstract}
:
This article explores, from the standpoint of sociopolitical myth-criticism, the processes of revision and adaptation carried out in Gary Owen's 2015 play Iphigenia in Splott. The play, a dramatic monologue composed in the rhythms of slam poetry, rewrites the classical Greek myth of Iphigenia in order to denounce the profound injustice of the sacrifices demanded by austerity policies in Europe-and more specifically, in Britain -in the recession following the financial crash of 2008. Reassessing contemporary social, economic and political issues that have resulted in the marginalisation and dehumanisation of the British working class, this study probes the dramatic and mythical artefacts in Owen's harrowing monologue by looking back to Euripides's Iphigenia in Aulis, the classical play which inspires the title of Owen's piece and which serves as the mythical and literary background for the story of Effie. The aim is to demonstrate how Owen's innovative adaptation of the sacrifice of Iphigenia, slurred out in verse, resentful and agonising, speaks out a desperate plea against myth, that is, against a dominant social ethos that legitimises its own violence against the most vulnerable- those who, as in the classical myth, suffer the losses that keep our boats afloat.
\end{abstract}

Keywords: Adaptation; Gary Owen; myth-criticism; Iphigenia; austerity 


\section{Introduction}

Gary Owen's Iphigenia in Splott was first performed at the Sherman Theatre in Cardiff on May 8, 2015. It went on to win, among other accolades, the James Tait Black Prize for Drama at the Edinburgh Festival Fringe and the UK Theatre Award for Best New Play in 2016, earning the acclaim of critics and audiences alike. Furious, sharp and witty, the play is a profoundly shattering monologue composed in the fast-paced rhythms of performance poetry that rewrites the classical Greek myth of Iphigenia in order to denounce the unfairness of austerity politics in Europe - and more specifically, in Britain —after the financial crash of 2008 and the economic crisis that followed. Fully imbricated with contemporary movements in British political theatre, Owen's play probes the limits of adaption, engaging in a process of mythical revision that posits the aesthetic exercise of literary reinvention as a practical tool for political protest. Iphigenia in Splott dramatises and exploits socioeconomic concerns and popular narratives that have dehumanised, stigmatised and marginalised the British working class in recent decades, only to then brutally debunk such narratives. It looks back to Euripides's Iphigenia in Aulis to continue the age-old trend of mythical adaptation, recreating the story of the tragic Greek princess-the daughter of Agamemnon who was sacrificed to the gods for the sake of Greece-amidst the drama of south Cardiff, where the life of impoverished Effie spirals in a turmoil of drunkenness and tragedy as she suffers the cruelty of welfare cuts in post-recession Wales. Experimental and frantic, Owen's play conveys the futility of an individual's selfdetermined story against the fatality of the myths that codify the ill-will of the gods. It readjusts, in the form of innovative political drama, the capriciousness of the ancient Greek divinities to cry out desperately against the cruelty of a dominant narrative, the myth of austerity, which legitimises its own violence and injustice.

\section{Rewriting Iphigenia: The Politics of Adaptation}

Linda Hutcheon famously defined the notion of 'adaptation' as "repetition with variation" $(2006,4)$ or, what is effectively the same, "repetition without replication" (7). She extended the definition to specify that an adaption needs to be an "extensive transposition" that "always involves both (re-)interpretation and (re-)creation" and constitutes, in fact, "a form of intertextuality," since we necessarily experience adaptations through our knowledge of the source material (7-8). Thus, adaptation implies change, but the alterations carried out with regards to the original are not arbitrary. They are an adjustment. Variation is required 
so that the source material is made suitable for the contemporary context. As Komporaly argues, the point is to change the story to make it "relevant for the here and now" $(2017,1)$.

Komporaly, indeed, goes as far as arguing that the convergence between a pre-existing source and a contemporary aesthetic trend, along with a concern for the ongoing socio-political circumstances, are "at the foundation of theatre making" $(2017,1)$. This is perhaps especially on point when discussing a kind of political drama that, as Fragkou notes, "saw renewed energy in bridging arts and activism" $(2018,175)$ with the reactivation of political action after 2011. Such plays-among which Fragkou specifically places Gary Owen's Iphigenia in Splott- "directly responded to the cuts using confrontational dramatic voices," and, "although not themselves performing direct street action, [...] capitalised on the politics of dissent and anger performed at grassroots level" $(2018,175){ }^{1}$ Significantly, going back to the issue of dramatic adaption, it may be helpful to note that this kind of intervention on a text "deliberately situates single-authored plays alongside performance work rooted in collaborative practice and devising" (Komporaly 2017, 2). Adaptation emphasises the collective, communitarian practice of theatre, which makes adaptations a particularly fruitful subgenre for the exploration of contemporary political drama. From this perspective, adaptation constitutes a dramatic strategy that helps tie together theatre and political action by providing reinventions and recreations of well-known stories that offer new approaches, often aggressive and dissident, that demand the interrogation of traditional meanings, and that allow for the transgression of boundaries (Komporaly 2017, 4). It follows then, unavoidably, that artistic experimentation cannot be detached from the socio-political consciousness of plays that provide "destabilising and deconstructive readings" and obey "a genuine desire for recontextualisation" $(2017,5)$. Thus, adaptation can logically be seen as a necessary process which alters the original work to make it applicable and relevant within the contemporary context.

Bearing this notion in mind, it is quite telling that, as Komporaly mentions, even though Ancient Greek theatre has always been present one way or another on international stages, "it has experienced an unprecedented uptake in recent years" in the English-speaking world $(2017,13)$ thanks to a wide variety of revivals, translations and adaptations that include, of course, Iphigenia in Splott. Owen's reinvention of the classical myth premiered in Cardiff in 2015, a year that, for dramatist Dan Rebellato, was "the year of the Greeks" (2015, para

1 Owen's affirmation that he "naively" hoped that the play would "send [...] people out into the streets" (Bano 2016, para. 25) reinforces the strong association of theatre and political action that characterises this trend of political drama. 
3). ${ }^{2}$ For Rebellato, the turn towards classical Athens is explained by austerity politics as Greek tragedies express the archetypal conflict of "human beings against the Gods, and against destiny and against their own fundamental weaknesses" (2015, para 5). These plays "remain political" and mirror the world of austerity economics, "a world of intense, friendless cruelty" (para 6-7). As Rebellato argues, if Euripides himself had been tasked to write a tragedy about the suffering of Greece under the policies of austerity in the year 2015, he would have specifically rewritten Iphigenia in Aulis, replacing the insanity of the Gods with the arbitrary, implacable and brutal decisions of the International Monetary Fund (IMF) (2015, para 7). ${ }^{3}$ Of course, Euripides did not rewrite the tragedy of Iphigenia, but Gary Owen did. While Owen did not explicitly denounce the cruelty of the European troika-the decision-making group comprising the European Commission (EC), the European Central Bank (ECB), and the IMF-that had so recently brought Greece to its knees, he did adapt Iphigenia in Aulis to tell a very similar story. The plot description that was used to promote Iphigenia in Splott can still be read today on the website of the Sherman Theatre:

Stumbling down Clifton Street at 11:30 am drunk, Effie is the kind of girl you'd avoid eye contact with, silently passing judgement. We think we know her, but we don't know the half of it. Effie's life spirals through a mess of drink, drugs and drama every night, and a hangover worse than death the next day-till one night gives her the chance to be something more. Effie will break your heart. Inspired by the enduring Greek myth, Iphigenia in Splott drives home the high price people pay for society's shortcomings. (2015, n.p.)

2 As Rebellato points out, in 2015 alone, the Almeida opened Robert Icke's retelling of Aeschylus's Oresteia, following up with the The Bacchae, Medea, a reworked Lysistrata, and a one-off performance of Homer's Iliad, which was also adapted by Mike Pearson for the National Theatre of Wales. Also, there was a re-working of Medea at The Gate, following a faux-classical Idomoneus; the classical tragedy A View from the Bridge in the West End, Oresteias at Shakespeare's Globe and Home Manchester, and possibly at the National Theatre of Scotland. Finally, the Unicorn also had a 'Greek season' in 2015, with retellings of the myth of the Minotaur and Odysseus (2015, para 3).

3 To better understand the symbolic identification between the arbitrary gods of mythology and international institutions such as the IMF, Harvey's explanation about the undemocratic practices of the neoliberal state are particularly eloquent: "To guard against their greatest fears-fascism, communism, socialism, authoritarian populism, and even majority rulethe neoliberals have to put strong limits on democratic governance, relying instead upon undemocratic and unaccountable institutions (such as the Federal Reserve or the IMF) to make key decisions" $(2005,69)$. 
Iphigenia in Splott was promoted as an adaptation, a reinvented version of a classical Greek myth that tells the story of a young girl enduring the sacrifices demanded by the policies of austerity in Britain after the economic crisis of 2008 . The play rewrites myth to articulate a social and political complaint. It retells an ancient tale to challenge today's dominant discourses and denounce the actual social and personal damage resulting from such political and socioeconomic discourses and policies. The result of this process of adaptation is the story of Effie, told in her own angry, inappropriate and upsetting words. It is a firstperson, self-mythologising protest that seeks to elevate and dignify through the reinvention of myth - or rather, in this case, through the debunking of myththe sacrifices endured by those who have suffered and are still suffering the cuts and losses that guarantee the growth and profit of others. Owen's adaptation is overtly political, but quite significantly, so too is the myth of Iphigenia. Despite the efforts to recontextualise Effie's tragic fate, Owen's alterations of the foundations of Euripides's text is not too abrupt. It continues-perhaps exacerbates-the ongoing transformation process that accompanies the evolution of myth across a never-ending string of literary representations.

Euripides's Iphigenia in Aulis was first produced posthumously at the Great Dionysian festival in $405 \mathrm{BCE}$, and most scholars today agree that it is likely that the Greek tragedian left the play unfinished, and that the text was completed by his son, who staged it one year after the author's death. It is also commonly accepted that, at some point, perhaps at the end of antiquity, the last pages of the play were lost and probably rewritten by someone else (Grene and Lattimore 2013, 87). As is well known in terms of the plot, the play enacts what Grene and Lattimore call "one of the most harrowing episodes in the tragic vicissitudes of the house of Pelopids, the royal dynasty of Argos" $(2013,88)$ through its dramatization of the myth of terrible cruelty:

\begin{abstract}
When the Greek armies under the command of Agamemnon gathered at Aulis in order to sail against Troy, they were held up by adverse winds. The Greek seer Calchas declared that they would be able to sail only if Iphigenia were sacrificed to Artemis; and Agamemnon, after some hesitation, agreed. The maiden was put to death by her father in front of the whole Greek army-though, according to some versions, at the very last moment the goddess miraculously rescued her and substituted a deer. $(2013,88)$
\end{abstract}

From the critical standpoint of myth-criticism-which is concerned with how myths are both perpetuated and inevitably transformed over time-it is crucial to understand that Euripides's play itself constitutes an instance of mythical adaptation: it re-enacts a story that Homer had previously narrated, and that 
Hesiod and Aeschylus, among others, had already poeticised. In rewriting the story, Euripides makes a series of dramatic and aesthetic choices that effectively give a particular shape to the well-known myth. He chooses a specific focus and concentrates on a single episode: the sacrifice of Iphigenia, which is dramatised, as Grene and Lattimore explain, "with a distinctive mixture of psychological intensity, pathos, irony, and astonishing reversals" $(2013,89)$. In this regard, it is worth noting that Euripides follows the tradition of the "'surviving' Iphigenia" (Hulton 1962, 364) — a tradition that, as Hulton explained, generated "a mass of legend" but is not the one that is most prominent in drama $(1962,364)$. This argument, of course, disregards the claim that, as argued by Grene and Lattimore, "the play, as presented in $405 \mathrm{BCE}$, probably ended at line 1531 with Iphigenia leaving the stage for her death and the chorus acclaiming her decision" $(2013,89)$, and instead accepts as canonical the ending of the manuscript in which a messenger recounts the girl's miraculous rescue when a doe is sacrificed in her stead on Artemis's altar. Nevertheless, whether the 'original' play follows, or not, the current of the 'surviving Iphigenia,' Hulton's explanation recognises divergent traditions in the dramaturgy enacting the myth, which allows for the argument that the dramatic performance of the myth constitutes - even in the Greek sources - a case of adaptation and reinterpretation. This notion is fundamental to critically explore how the myth, in the shape of drama, has been adjusted to specific contexts throughout the centuries. Following the previously established notion that the practice of dramatic adaption has proved particularly fertile for the connection of theatre and politics, looking at the Greek source through the lens of mythical reinterpretation might contribute to a more solid understanding of the myth of Iphigenia from an eminently political standpoint, which in turn can help to assess its present relevance in the context of contemporary British political drama.

In this regard, Sorum's argument concerning mythical adaption in Euripides is very eloquent. She supports her study of Iphigenia in Aulis with the notion that Greek tragedies "exploit the tension that arises between the myth and the dramatisation of the particular moment," which, she points out, is crystalised in Euripidean drama through the tension between an accepted version of myth and the dramatic fiction itself, which becomes somehow self-conscious in it "literary" nature $(1992,529)$. In Iphigenia in Aulis, the weight of myth is undeniable, as Euripides's text, in its merging of the epic and the tragic, combines two mythological traditions: the stories of the Trojan War and those of the House of Agamemnon. As Sorum explains, "[the] combination of the two stories makes explicit both the past and future of the dramatic fiction" $(1992,530)$. The audience knows what came before, and what will inevitably happen later. However, as previously suggested, "the stage action of the drama [...] focuses only on the moment in which Agamemnon must choose whether or not to proceed with the sacrifice of 
his daughter. This moment seems critical, for the choice will determine whether or not the expedition will sail, the war will take place, and Agamemnon will return to a hostile home" (Sorum 1992, 530). The play, again and again, emphasises moments of choice. Characters change their minds so frequently that, as is well known, Aristotle criticised the play's alleged inconsistency in his Poetics with the argument that "the girl who beseeches is in no way like her later self" (quoted in Moorwood 2001, 607). The significance of Iphigenia's change of mind will be addressed later on, as part of the discussion about the political intricacies of Gary Owen's adaption. However, at this point, it seems crucial to follow Sorum's argument that, "when Iphigenia begs her father to spare her, it is the mythological and poetic reality that she must seek to change as well as her father's mind" (1992, 538-9). Her "beseeching" then, to quote Aristotle, establishes the possibility of an alternative story, of the dramatic fiction becoming "antimythical" (Sorum 1992, 536). However, Iphigenia's final embracing of death reconciles dramatic fiction and mythical tradition $(1992,542)$, as also happens when Effie changes her mind at the end of Iphigenia in Splott. Both texts raise the possibility of a different version of the story, of modifying mythical tradition through the action of dramatic fiction. In doing so, both Euripides's and Owen's plays in effect reshape the myth; but far from simply rejecting tradition, both texts adopt and exploit it to denounce the inherently violent ethics which, in the myth, objectify and condemn the most vulnerable among us.

It is indeed noteworthy that, while Iphigenia in Aulis does not seem to have been one of Euripides's most popular plays during antiquity, it has proven to be one of his most successful in the contemporary world (Grene and Lattimore 2013, 90). As explained by Greene and Lattimore, it was first translated into English by Lady Jane Lumley in 1558, and there have been many relevant theatrical versions from the 17th century onwards, including plays by Racine, Schiller, Hauptmann, Rexroth, and even Lorca, who drafted but never finished a piece $(2013,91)$. In addition to dramatic renderings, over the centuries, the sacrifice of Iphigenia has also drawn the attention of painters, composers, and filmmakers, among others. ${ }^{4}$ To better contextualise Gary Owen's adaption, however, one must consider the play's continued vitality onstage in the $21 s t$ century in the Anglophone context, recent years having seen contemporary

4 Some relevant examples listed by Grene and Lattimore (2013, 90-91) are paintings by Domenichino (1609), Giovanni Battista Tiepolo and his son Giovanni Domenico Tiepolo, Jan Steen (1671), Jacques-Louis David (1819), Mark Rothko (1942) and Paul Delvaux (1968). They also mention operas by Domenico Scarlatti (1713), Christoph Willibald Gluck (1774) and Luigi Cherubini (1782), along with many 20th-century versions like Isadora Duncan's ballet (1905), H.D.'s choral songs (1915), Zbigniew Herbert's poem (1957) and Michael Cocayannis's film (1977). 
rewritings of Euripides's classic as inspiring and thought-provoking as Neil LaBute's short play Iphigenia in Orem (2000), Caridad Svich's multimedia play Iphigenia Crash Land Falls on the Neon Shell That Was Once Her Heart (a rave fable) (2004) and Charles L. Mee's Iphigenia 2.0 (2007) (Grene and Lattimore 2013, 91). For Grene and Lattimore, the continued vivacity and energy of Iphigenia's story in contemporary drama is explained by the fact that "as long as audiences continue to be fascinated by the violence of men against women, the bloodthirstiness of war, and the conflict between moral nobility and sordid utilitarianism, Iphigenia in Aulis will surely remain popular" $(2013,91)$. This certainly sounds plausible, but Owen's 2015 Iphigenia in Splott does not seem to be specifically about the violence of men against women, even though it is a man who victimises Effie; or about the bloodthirstiness of war, even though dead and amputee soldiers, victims of the war in Afghanistan, appear in the play. Neither does the play seem overly concerned with moral nobility, even though Effie, self-defined as a "stupid slag" and a "nasty skank" (Owen 2015, 1), proves to be very noble in her final act of self-sacrifice. Perhaps more evidently, Owen's play is about the sordid utilitarianism that objectifies individuals for the sake of a supposed common good that, like the ancient myth that forces the hand of dramatic fiction, legitimises violence against the weakest and most defenceless.

\section{Ferocious Tragedy: The Pathos of Effie's Complaint}

Effie's monologue begins as she directly confronts the audience, addressing the spectators unapologetically and rather disdainfully. She accuses them of just "sitting back, taking it easy" as they wait for her to impress and amaze them $(2015,1)$. She crudely corrects their expectations: "You have got it back to front, arse about it, and your up side / Is definitely down" (1). She immediately explains what she means, revealing the fact that the audience's misconceptions run deeper than one may initially suspect: "See I know what you think / When you see me pissed first thing wandering around. You think - / Stupid slag. Nasty skank. / But guess what? Tonight / You all are here to give thanks / To me" (1). Her words aim to shock the spectators, to warn them, to agitate them as she challenges their prejudices: "Yeah I know it's a shock. / But you lot, every single one / You're in my debt. / And tonight - boys and girls, ladies and gents - / I've come to collect" $(2015,1)$.

Effie's attitude resounds with the echoes of what Sierz termed 'in-yer-face theatre,' which he described as "any drama that takes the audience by the scruff of the neck and shakes it until it gets the message" (2014, Ch. 1). 'In-yer-face' plays can do this in varied ways: they may use shock tactics, an unexpected tone or structure; they can be extremely experimental or smash taboos; but in every case, 
this kind of theatre creates discomfort, gets under the skin, attacks the audience's prejudices and forces them to confront feelings and ideas that are painful and unpleasant (2014, Ch. 1). Iphigenia in Splott meets these criteria squarely and, even though Sierz's book predates Owen's play, in a previous study, the critic had pointedly defined Owen's English-language work as "an example of British new writing, all verbal acrobatics and in-yer-face ferocity" $(2011,158)$. Of course, "inyer-face' drama sprang up as a trend in contemporary British theatre in the 90s when "a host of plays by young writers used explicit and directly confrontational material to explore the way we live and feel" (Sierz 2014: Ch. 1). Owen's play was written and performed almost two decades later, and, as previously argued, it is best inscribed within the movement of political drama that surged in Britain after the 2008 recession. Nonetheless, the essential fury and combativeness of 'in-yerface' theatre resonate loudly in Effie's enraged monologue.

Ben Brantley, a critic on the New York Times, wrote in his review of the play that "it's not easy for a theatregoer to be the focus of so much rage and resentment" (2017, n.p.) — a very acute observation that reveals how Owen's adaptation engages the audience. In her analysis of Owen's very well-known play Ghost City (2004), Kbłowska-Ławniczak explains that Owen's drama exposes the audience to another's inexpressible suffering, involving both subject and spectators in the recognition of that suffering, and thus "infecting" the audience with "a sense of guilt" that forces them to probe their "susceptibility towards suffering and injustice" (2014, para 7). Such is the discomfort created by Effie's furious tragic monologue. Iphigenia in Splott forces the audience to confront human cruelty by recognising in their own indifference just such cruelty. The emotional trouble provoked by the play stems from the audience themselves confronting the truth contained in Effie's tragedy. As the character's initial words make explicit: the audience is there to give thanks. They owe Effie, and, as she warns them, that news, in line with classical 'in-yerface' theatre, will come as a shock to the spectators (Owen 2015, 1).

Angelaki (2017) argues that "theatres of crisis"-plays produced on the British stage after 2000, especially in the post-recession period after 2010, which denounce how the individualism promoted by neoliberalism has colonised every aspect of human experience (5) - are plays that disturb so they might disrupt "first our expectations, then the dominant social and political narratives of neoliberalism and governmentality" (3). They are plays that, as explained in the previous section of this essay, exist in the space between the aesthetic and the social, connecting arts and politics, and allowing a new form of social performance where adaptation and experimentation coalesce to shock the audience into action or, at least, towards recognition. One way Iphigenia in Splott partakes in this trend is through a very specific form of formal and aesthetic experimentation: what critic Lyn Gardner refers to as the play's "dirty poetry" (2016, n.p.). 
Effie's monologue is written in verse. It resounds unexpectedly with the flexible rhythms and the anger of slam poetry, a very popular genre-for some "the largest and most influential social/literary arts movement of our age" (Smith and Kraynak 2009, 24) — that, anecdotally, for Harold Bloom was nothing if not "the death of art" (quoted in Sommers-Willet 2014, 2). Of course, the term 'slam poetry' refers to a specific kind of poetic event in which the audience's attention is drawn to the presentation of "poetry that's been composed, polished, and rehearsed for the purpose of being performed" (Smith and Kraynak 2009, 3). Very often, in this kind of event slam poets present their work in the context of a competition, but what is most relevant to appreciating the tone and form of Effie's monologue is a consideration of slam poetry's "grudge" (Sommers-Willet 2014,1 ), that is, the social protest typically found in such poetry, uttered against dominant culture in the voice of the marginalised. Sommers-Willet points out that in slam poetry, there is a "sense of subalternity" $(2014,3)$, also found in the broader and more diffused realm of spoken-word poetry, ${ }^{5}$ that is patent in the words of Effie. Owen's text is not performance poetry, but it is a piece of drama that reverberates with the cadence of a poetry of protest that shows resistance to dominant public culture, and where the form and rhythm of verse are effectively used to strengthen dramatic pathos:

And he pulls his jeans down. And his legs

Are lovely

But one of them

Stops.

At the knee.

He sits back kick off his jeans and

His right leg. It's plastic from the knee down.

He gets to work on the buckles.

Pulls the plastic free

And something comes out.

A stump of flesh, that just ends.

The skin folds over

5 Fowler explains that contemporary British poets that perform their poetry tend to reject being categorised as 'performance poets,' considering the term 'spoken word poet' to be reductionist $(2016,177)$. As she notes, 'spoken word poetry' is often a contested category, as it implies a separateness of oral and printed poetry that touches on the issue of literary status, "pointing to a long-standing poetic injustice in Britain whereby influential publishing houses rarely endorse poetry associated with the performance scene" (2016, 177). This lack of parity is of course part of a longer, unresolved argument about what poetry is and who is it for $(2016,177)$. 
To a red, angry ridge,

Black stitch marks where they stuck

The flaps of skin together.

How'd it happen? (Owen 2015, 19-20)

Effie voices her pain in verse and swear words,${ }^{6}$ the rhythm and intensity fluctuating along with her hope and anger. Performance poetry usually rallies the audience around its liberal politics and its support for marginalised groups and identities (Sommers-Willet 2014, 2), but the frantic, aggrieved poetry coming out of Effie's mouth is much less benevolent with the spectators. Echoing with the fury of 'inyer-face' drama, Effie's monologue provokes alarm and troubles the emotions of the audience. She grabs the audience by the neck as she forces them to listen to her first-person, heart-wrenching account of the death of her premature daughter:

I hear my baby girl cry-

—and I hear her stop

And they take her

The two of them

Bent over this tiny scrap

They've got a mask over her face

They're pounding on her chest

They're pulling needles out of plastic

Trying to stick 'em in her

But she's too small

She's too small [...]

They're fighting

They're fighting with everything they got

To keep her with me.

And they fight

And they fight

They fight for so long.

And then

They stop. (Owen 2015, 58-59)

6 A good example of how the cadence of verse mixes with Effie's rough, often-shocking language can be observed in the following lines: "The crowd shifts, / And the gang he's got surrounding him move / And I can see the guy / Head to foot. / And what I see is_ / - the fucker's on crutches. / And he sees me see. / He sees me, laugh. / At him, and, at me, / trying to lure him to the dance floor, / When the poor fucker can't walk. / So I walk, for him. / All the posturing and posing gone. / I put my arms round his neck. / I say, / Hello, you. / And I snog his fucking face off" (Owen 2015, 16).

Alicante Journal of English Studies, Issue 35, 2021, pages 119-140 
The abruptness of the free verse, the faltering rhythm, the constant repetition of words and structures, and the lack of punctuation evoke the anguish of a woman choking with excruciating, ineffable pain. The audience, addressed directly, is forced to see the violence of the system that guarantees their wellbeing. Confronted with another's suffering, the spectators have no choice but to engage and then to respond with shame and guilt when they realise that Effie is right. Like the mythical Iphigenia, her sacrifice has saved every one of us, and by recognising in her sorrow the violence of our social arrangement, we either take responsibility for her loss, or we partake willingly in the cruelty of the gods that have condemned her.

\section{Against Austerity: Resisting the Violence of Myth}

As Effie insists from the very beginning of her story, we all know who she is, where she lives, and what part of society she belongs to. She knows that we know, and she knows what we think of her. She admonishes us, saying: "I strut down the street, and your eyes dive for the ground / Face on I'm too much for you to handle" (Owen 2015, 1). Her aggression toward the audience-"I live my life a million miles an hour, do what I like, when I like, and / Oh look, I've got — this — for you, if you can't deal with it" $(2015,2)$ — mixes with very specific details describing the harsh conditions of life in her neighbourhood: "Nan says, this place used to have everything you need / Shops are gone, bingo hall burned, pubs closed, doctors shut, / STAR centre getting pulled down and more flats thrown up. / She says we used to live. You could live here and live well. / Now they're stacking us up, and we're supposed to just exist" (2).

As Owen himself explains in an interview, the social provision cuts described in the play expressively convey a very specific sense of place. Splott, in Owen's words, is a neighbourhood in Cardiff where people "are struggling and don't have much money, where people are particularly dependent on public services, and in which those public services are being withdrawn" (Bano 2016, para 17). As he clarifies, "almost everything that's mentioned in the play about libraries closing and play centres being shut down are just literal things that are happening in Splot right now" (17). Indeed, as Internet blogger and theatre critic Megan Vaughan writes in a rather critical appraisal of Owen's play, Effie "ha[s] been beaten into a hopeless routine by geography and poverty and, longer ago, by the slow murder of British industry" (2016, para. 3). Deindustrialisation,

7 A footnote in the play explains: "[Effie] finds some cute way to give the audience the finger" (Owen 2015, 2). The physical insult works well as a particularly eloquent metaphor to express how Effie feels about the theatre-goers listening to her story. 
along with the withdrawal of the state and their disastrous consequences for the working class adopt a mythical shape in Owen's verse-the play, after all, adapts Euripides and mythologises Effie-but the text's strong sense of place remains untouched in Effie's eerie description of Cardiff's post-industrial landscape. As she walks down busy roads that "have gone quiet for the night," she moves "past the big Tescos, past David Lloyd / To all the massive factories like / Crashed spaceships, the metal mountains, / Train tracks from nowhere, cranes and pipes and chimney stacks" (Owen 2015, 24-25). Movingly, she recognises that the ghostly wasteland is scary, but it retains a touch of magic: "a couple of gypsy ponies find me, / Wander up the verge, bump their big heads against mine, telling me / Keep going, you'll be fine" $(2015,25)$.

The immediate social and economic contexts of the play are the post2010 cuts implemented by the Conservative and Liberal Democrat Coalition government as part of their austerity programme, which, while very much in line with the politics of austerity dictated across the European Union by the EC, the ECB and the IMF, represented, in the British context, "an extreme form of Thatcherism [...] based on a neoliberal commitment to minimising the state as far as possible" (Rebellato 2015, para. 8). For authors such as Cooper and Whyte, the austerity economics that followed the financial crash of 2008 was precisely this, an opportunity to advance the neoliberal policies that, since the early 1980s, had promoted growth through private investment and deregulating the movement of capital $(2017 \mathrm{~b}, 20)$. The exacerbation of such policies in the recession years-a period that has been termed 'austerity Britain'-resulted, in their opinion, in "a suite of irrevocable reforms to welfare benefits, housing, pensions, higher education, privatisation and so forth" (2017b, 20). Of course, as McKenzie argues, these cuts were particularly drastic in terms of unemployment benefit, disability benefit, income support and housing benefit, which aggravated the desperate situation of families and communities that were already in a very dire situation before the crisis $(2015,10)$. As Owen himself argues, the most vulnerable are "the ones that face the worst cuts even though they're the least able to take them" (Bano 2016, para. 17)—a dismal circumstance which is particularly desperate in Splott, where people "are very, very dependent on public services-libraries, community centres, Sure Start-and all these things are being threatened" (Owen, quoted in Trueman 2016, para. 3).

Effie is of course a victim of these policies, but it takes a while for the audience to recognise her as such. Unemployed, living off 20p noodles and only getting through the week thanks to a never-ending cycle of hangovers that allow her "an escape from real life" (Owen 2015, 5), Effie very much fits the stereotype of the demonised working-class girl. As Owen Jones has famously argued, the working class in Britain was disarticulated by Thatcher's rampant neoliberalism, being 
degraded from a proud, rebellious and syndicated group to a people that was unemployed, dependent and-very expressively depicted in how Effie is presented to the reputable audience- the victim of an integral form of class hatred that has become part of respectable modern British culture (Jones 2011, 6). Perhaps, in terms of the audience of Iphigenia in Splott, hatred is too strong a word, but as Effie introduces herself, describing in gruesome detail her daily routine, the character certainly seems off-putting. She irreverently informs the audience: "See the only way I get through the week is a cycle of hangovers / And I'm not talking, bit of a baddy head here. / I'm talking proper, brain-shredding three day bastards" (Owen 2015, 3). Once again, the specificities in her sordid speech effectively ground the text in a very specific time and place: "I'm talking hangovers that start, you're under a table at Chicken Cottage, / You've already chucked so much you're just heaving big empty sick-flavoured burps, till / Some secret trapdoor springs open in your guts / And this thick green gloop shoots out your gob / This sour liquorice juice, pints and pints of it" $(2015,3)$. The attempt to offend and disgust the audience is deliberate and very well-founded on the spectators' prejudices: Effie feels no shame in admitting that, when she wakes up after a night of heavy drinking and partying, she does so "in a stranger's bed, or a bathroom floor, or police cell" $(2015,3)$. Yet, a disquieting hint of misery transpires in her words when she admits that her drinking spree sorts out half of her week,

Because you'll be day one in bed, crying and wishing you were dead, Onto the settee for day two, sweating into your duvet, eating twenty pee noodles, watching whatever shit comes on Dave ja vu.

And on the third day you rise, and put yourself back together; start with a scalding hot bath mid morning to lift the shit from your pores then a ten hour programme of sanding down surfaces, picking, plucking, painting before you're ready to again. (Owen 2015, 4)

Effie fits perfectly with what McKenzie has described as "the myth of the benefit scrounger" so often portrayed in what she calls "poverty porn" narratives (2015, 12). As she explains, it has become a sort of default, and quite a popular opinion, "that those who live on council housing estates in the UK are overly dependent on welfare and state benefits, because of their own 'lifestyle choices,' using taxpayers' hard-earned money seemingly to live the life of 'Riley,' which often includes taking drugs, drinking alcohol and generally having a great time" (2015, 12). At the same time, Burnett refers to TV programmes like "Benefits Street" and "Immigration Street," in which individuals are subjected to ridicule and contempt, becoming, as a result, victims of class hatred precisely because the blame for the economic crisis is placed on the victims $(2017,217)$. Owen's play, 
as argued, begins by feeding into that popular opinion, which is ingrained in its audience's prejudices. It reinforces that bias; it builds up the myth of the scrounger and engages spectators by strengthening a set of preconceptions that reaffirm their middle-class worldview in a way that feels reassuring and comforting. Then, of course, it pulls the rug out from under their comfortable feet when through the story of Effie's tragedy it reveals that, as McKenzie demonstrates, a life of unemployment and benefit claiming "has always meant a life of poverty, insecurity, and precarity" $(2015,13)$.

Unmaking the myth of the benefit scrounger is a political action, the impact of which should not be underestimated. As Clarke explains, in advanced democratic societies, "the exclusion of a substantial proportion of the population from economic and political power depends on the ability of dominant groups to determine how the less fortunate are perceived and to limit empathy with them" $(2013,325)$. Such is then the function of the myth. Breaking down the myth entails delegitimising the basis of our modern democratic societies by revealing the violence that supports the comfort of some at the cost of the suffering of others. The effect of the myth is quite evident. It presents unemployment and poverty, as Jones writes, not as flaws within capitalism, but as "the consequences of personal behaviour, individual defects, and even choice" (Jones 2011, 10). ${ }^{8}$ This is an essential ideological foundation of the neoliberal state, as Harvey explains:

While personal and individual freedom in the marketplace is guaranteed, each individual is held responsible and accountable for his or her own actions and well-being. This principle extends into the realms of welfare, education, health care, and even pensions [...]. Individual success or failure are interpreted in terms of entrepreneurial virtues or personal failings [...] rather than being attributed to any systemic property (such as class exclusions usually attributed to capitalism). (2005, 65-66)

The myth of the scrounger-supposing that Effie is telling the truth when she declares, "I live my life a million miles an hour, do what I like, when I like" (Owen 2015, 2) —certainly reinforces the conviction that personal failure can be

8 This is not only a generalised opinion reinforced by neoliberal dominant discourses and media. It is written policy. When it appeared in the Breakdown Britain report, that is, the document that supported many of the welfare cuts implemented by Iain Duncan-Smith, Conservative Party Secretary of State for Work and Pensions (2010-2016), there existed in Britain five poverty drivers: family breakdown; welfare dependency; educational failure; addiction to drugs and alcohol; and serious personal debt. As McKenzie notes, "all of this squarely puts the problems of society on the individual [...]. It is personal failure and "bad behaviour' that has broken Britain" $(2015,11)$. 
attributed to personal failings. The consequence of this is that the victim-more and more exposed to poverty as the state withdraws from providing health care, education or social services-is often blamed for their own suffering (Harvey $2005,76)$. Translated to mythical terms, Iphigenia, since she chooses to die to save her father's boats in the classical version of the story, is the only one to blame for her own tragic fate.

And so is Effie, apparently. In Owen's contemporary political adaptation, Iphigenia is placed alone upon the stage. She is the left-behind, isolated individual in a post-industrial city in post-austerity Britain. Like in Euripides's play, Effie faces a choice. When her premature baby dies in an ill-equipped ambulance while they are being transferred to another hospital because there are not enough beds in special care, Effie decides to "make / The fuckers / Pay" $(2015,60)$. She is guaranteed several hundred thousand pounds in compensation, and she realises what that could mean: "Get me a house. / Get me a car. / Get me by; for years and years" $(2015,61)$. She is thus promised the new, right kind of aspiration in the neoliberal state, that being, "individual self-enrichment: [the chance] to scramble up the social ladder and become middle class" (Jones 2011, 10). It is a tragic, perverse spin on the myth of the scrounger in the way that it confirms the words of Effie's boyfriend when he tries to convince her to have a baby: "Once you got a kid, you're sorted you get / Child allowance, loads of shit. / Kid's basically a fucking meal ticket" (Owen 2015, 43). Owen's undermining of the popular narrative that dehumanises people on benefits is striking in its cruelty: the harsh conditions of Effie's life are most likely the cause of her going into labour early, and the austerity cuts deny her the standard of healthcare that could have saved her daughter. ${ }^{9}$ The audience is forced to face the tragic consequences of Effie's desperate situation, to listen to the agony in her soliloquy, to contemplate the irony of this 'benefit scrounger' getting the chance to sort out her life by collecting several hundred thousand pounds as compensation for the death of her baby girl- the damage done by the state that has abandoned her.

Effie becomes Iphigenia at this moment. As in Euripides's tragedy, she chooses to surrender to myth. She succumbs to the ethical framework that not only permits but encourages and legitimises her sacrifice when she drops the case against the hospital after she speaks with the midwife who was alone on her shift and thus could not assist her the night her baby was born. The midwife

9 According to data from Eurostat and the 'Inequalities in Child Health' report published in 2013 by the BMA Board of Science, Mack explains: "The UK infant (0 to 1 years) mortality rate, at around four deaths per 1000 births in 2014, is higher than all but two of the nineteen Euro area member states. About half of these deaths are linked to short gestation and low birth weight, both of which are highly associated with deprivation" $(2017,89)$. 
laments that she could not have saved Effie's child even if she had been able to assist her, because what Effie's premature daughter needed was "to be born in hospital. In a special care unit. / Where we'd've had the facilities, to look after her" (Owen 2015, 62). But Effie's baby was born in an ambulance because, as the midwife explains, "we didn't have a special care bed left. / We don't have as many special care beds as we used to / Cos of all these cuts" $(2015,62)$. Then, she presents Effie with a terrible choice: "If we pay you, we'll have to cut more. / And more old people will die before they should. / More young people will never get a chance to live. / And more mums, just like you, will lose-" $(2015,62)$.

For the play's director Rachel O'Riordan, the NHS's whole ethos is that "the fit and able can support and look after those who aren't fit and able" (Cooper 2016, para. 22). The play, however, presents the opposite ethos-the ethos of the myth of Iphigenia, what Habash defines as a specific kind of nomos, an ethical context that operates as "an almighty power that legitimates its own violence" (2017, 177). Habash refers to the words of the Chorus in Euripides's play as they comment on the sacrifice of Iphigenia: "Oh, where now has the countenance / of Modesty or Virtue / any strength, / when the blasphemer rules, / and heedless men / thrust Virtue behind them, / when Lawlessness rules law, /and no man competes with his neighbour / to avoid the ill-will of the gods?" (Grene and Lattimore 2013, 1089-1097). If the law, that is, if the ethical context-myth, the will of the gods-is ruled by lawlessness, then it becomes true that, as Judith Butler wrote in her commentary on Antigone, "doing the right thing according to established law is precisely what must be suspended in order to dissolve a body of established law that is unjust" (quoted in Habash 2017, 180). From this alone may follow the subjectification of an individual that has been commodified.

Effie, like Iphigenia, decides to sacrifice herself for the greater good. She simultaneously takes on Agamemnon's role, losing her daughter for the sake of the community. Her tragedy bears the weight of the myth of austerity, "a kind of smash and grab politics [...] supported by a deeply moral and ideological set of principles $[\ldots]$ a narrative that is apparently more plausible and more complex than class domination; a narrative that brings us all together around a common sense: we maxed out our credit card; we are all in this together; and we all stand to gain after the dust has cleared" (Copper and White 2017, 22). But there is nothing to gain for Effie. Like the version of Iphigenia recreated in Euripides's text, Effie abruptly changes her mind about retribution in a second act of sacrifice in favour of her ethical context: "I don't, make anyone pay. / Because there are years and years ahead of me / That were gonna be filled with loving her, / And getting loved back" (Owen, 2015, 64). The weight of her sorrow is somehow lifted by her trust in the myth that has demanded the sacrifice, through her belief that, in truth, we are all in this together. She admits that she thinks about committing suicide, about taking 
"that broken brick road to the sea / Not a mile away" $(2015,64)$. But she keeps going, sustained by the knowledge that her loss has saved our boats:

I took this pain,

And saved every one of you, from suffering the same.

Your baby gets sick, she gets well

Because of me. Your mum gets ill

She gets healed, because of me and still:

You see me, pissed first thing wandering home

And all you think is, stupid slag. Nasty skank.

When what you should be thinking is,

Christ Effie, thanks. You took the cut, for all of us. $(2015,64)$

For Cooper and Whyte, "the purpose of the violence of austerity is not simply to stabilise the economic system in the aftermath of the financial crisis but to stabilise it in a particular form that enables the rich to sustain opportunities for wealth generation" $(2017 \mathrm{~b}, 15)$. In the realm of mythical adaptation, the politics of austerity guarantee that the Greek kings will get to sail their boats, fight and eventually win their war-but their prosperity relies on the suffering of the most vulnerable, who support the weight of ensuring the success of a society from which they have been marginalised. The myths of austerity naturalise the violence within our communities. The myth of Iphigenia allows us to recognise the cruelty of a world where the fate of some is in the hands of arbitrarily and whimsical divinities. Owen's adaptation of Euripides's play corroborates Rebellato's assessment that the cruelty of myth is the same, whether the gods sit in Brussels or Parnassus, Frankfurt or Olympus (2015, para 10).

\section{Conclusions}

After the analysis conducted so far, the question remains as to whether Effie's final sacrifice in renouncing her right to claim damages is an act of free choice or an unwilling defeat in the face of the inevitability of a myth that, as in Euripides's play, determines the past and future of her story. Habash argues that, in Euripides's play, "Iphigenia decides to die after her begging fails to convince her father (1211-52), after Agamemnon reasserts the need for the sacrifice (1255-75), and after Achilles does not succeed in his attempt to rescue her and is violently rejected by the Greek army for his effort (1345-70)" (2017, 171). She chooses to die after she is told that she must die; that is, "her will is dictated from the outside" $(2017,172)$. She becomes an active subject in the making of a choice, but that choice is "performed in the name of a nomos 
that does not problematise the violence against her body and her death. She is immediately 'sucked' into social normativity" $(2017,173)$. She is also sucked into the dynamics of a myth that trumps dramatic fiction: she must die, for the boats must sail and Troy must fall. Myth goes on, unperturbed.

Effie is also "sucked" into the dynamics of myth when she makes her final sacrifice because myth is the ethical framework that legitimises her suffering. Myth is the greater good. Myth is austerity economics. Myth is the inevitable "illwill" of the gods, against which Effie futilely attempts to rebel. Upon revisiting the play, it is heart-breaking to notice how Effie interprets the events leading up to her unexpected pregnancy as "fate" (Owen 2015, 18), as her finally finding "what [she is] for" $(2015,26)$. The moment in Owen's adaption when "nasty skank" Effie becomes the "savior of Greece" (Grene and Lattimore 2013, 1383) is the moment that denounces the impossibility of a different story. At the end of the play, Effie wanders home, past "the pubs that shut, the library they closed, / The swimming pool got knocked down, / The bingo hall they burned / So they could turn it into flat" (Owen, 2015, 64). She contemplates the many losses that the myth of austerity has imposed on her community, realising that there are "more and more people packed in this little plot of land, / While they cut everything we need to make a life" $(2015,64)$. In her final words, as she denounces the fact that "it's always places like this / And people like us who have to take it, / When the time for cutting comes" $(2015,65)$, and poses a question for the audience: "And I wonder: just how long / Are we gonna have to take it for? / And I wonder - / What is gonna happen /When we can't take it any more? $(2015,65)$.

Some critics have deemed these last words "the start of a revolution" (Hayton 2015, para. 4), prompting the left-wing oriented, middle-class theatre audience to feel fear rather than empathy towards Effie. However, there is also the possibility of understanding the ending of Effie's monologue as an honest question. There is also the possibility of openly wondering what would happen when the most vulnerable cannot take it any longer. Perhaps, then, the story could change, the boats not sail, and Greece not be saved. Myth could be rewritten, and the ethical context rebuilt. For if the myth is remade, the social structures it sustains will predictably fall. From this perspective, in consequence, a myth-critical appraisal of Iphigenia in Splott is particularly enriching. Owen's play is an overtly political adaptation of a classical tragedy, very much in line with dominant trends in Britain's contemporary theatre of crisis. But it adds to dramatic adaption an exercise in mythical revision that bridges mythopoeia and political activism. The play construes its protagonist upon the dehumanising myths of neoliberal policies — such as the myth of the benefit scrounger-only to debunk these myths when Effie transforms from foulmouthed chav to mythical princess Iphigenia. Then, Owen dramatises the futile struggle of Iphigenia against 
the broader mythical paradigm that sustains the ethos of contemporary Britain. For Cooper and Whyte, to fight austerity means to ensure that "its violence is not normalised or taken for granted as a legitimate political strategy" (2017b, 25). Iphigenia in Splott, on the other hand, does precisely that. It unmakes the austerity narrative of the recession period, offering as an alternative an attempted struggle, an outspoken recognition of the illicit violence of a myth that the play refuses to accept in its legitimation of unjust politics.

\section{Works Cited}

AngelakI, Vicky. 2017. Social and Political Theatre in 21st-Century Britain: Staging Crisis. London and New York: Methuen.

Bano, Tiм. 2016. "Gary Owen: "This is not a time to be subtle." Exeunt Magazine, January 25 2016, http://exeuntmagazine.com/features/gary-owen-this-is-not-atime-to-be-subtle [Accessed online on June 11, 2021].

Brantley, Ben. 2017. "A Mythic Force of Anger, Raging in Wales." New York Times, May 18 2017, https://www.nytimes.com/2017/05/17/theater/iphigenia-insplott-review.html [Accessed online on September 3, 2018].

BurnetT, Jon. "Austerity and the Production of Hate." In David and Whyte 2017, 217-223. https://doi.org/10.2307/j.cttlpv8988.28

Clarke, Ben. 2013. "In Pursuit of the Working Class." Cultural Studies Review 19 (2): 324-334. https://doi.org/10.5130/csr.v19i2.3476

Cooper, Neil. 2016. "Devastating Portrait of Britain's Underclass is Lost on Politician." The Herald, March 1 2016, https://www.pressreader.com/uk/theherald/20160301/282200830003393 [Accessed online on September 3, 2018].

Cooper, Vickie and Whyte, David, eds. 2017a. The Violence of Austerity. London: Pluto P. https://doi.org/10.2307/j.cttlpv8988

- 2017b. "Introduction: The Violence of Austerity." In Cooper and Whyte 2017, $1-33$.

Fowler, Corinne. 2016. "The Poetics and Politics of Spoken Word Poetry." In Osborne 2016, 177-192. https://doi.org/10.1017/CCO9781316488546.011

Fragkou, Marissia. 2018. Ecologies of Precarity in Twenty-First Century Theatre: Politics, Affect, Responsibility. London and New York: Methuen.

Gardner, Lyn. 2016, "Iphigenia in Splott Review—a Raucous, Brawling Call for Revolution." The Guardian, January 31, 2016, https://www.theguardian. com/culture/2016/jan/31/iphigenia-in-splott-review-national-theatre-londonsherman-cymru-gary-owen-sophie-melville [Accessed online on January 12, 2020].

Grene, David and Lattimore, Richmond. 2013. Euripides V. The Bacchae. Iphigenia in Aulis. The Cyclios. Rheus. Chicago and London: The U. of Chicago P. 
Harvey, David. 2005. A Brief History of Neoliberalism. Oxford: Oxford U. P. https:// doi.org/10.1093/oso/9780199283262.001.0001

HaYton, Andrew. 2015. "Iphigenia in Splott Five-star Review-a Whirlwind of Aggression and Seduction." The Guradian, May 14 2015, https:/www. theguardian.com/stage/2015/may/14/iphigenia-in-splott-review-shermancardiff-gary-owen [Accessed online on September 3, 2018].

Hulton, A. O. 1962. "Euripides and the Iphigenia Legend." Mnemosyne 15 (4): 364368. https://www.jstor.org/stable/4428688 [Accessed online on September 5, 2018]. https://doi.org/10.1163/156852562X00280

Hutcheon, Linda. 2006. A Theory of Adaptation. New York and London: Routledge. https://doi.org/10.4324/9780203957721

Jones, Owen. 2011. Chavs. The Demonization of the Working Class. London and New York: Verso.

Keblowska-Lawniczak, Ewa. 2014. "Forms of Togetherness in Contemporary Urban Drama and a Return of Direct Address." Interactions: Ege Journal of British and American Studies, 23 (1-2): n.p. https:/www.academia.edu/11312683/Forms_ of_Togetherness_in_Contemporary_Urban_Drama_and_a_Return_of_Direct Address [Accessed online on January 8, 2020].

Komporaly, Jozefina. 2017. Radical Revival as Adaptation. Theatre, Politics, Society. London: Palgrave MacMillan. https://doi.org/10.1057/978-1-137-48102-3

Habash, Nicolas L. 2017. "Lawlessness Controls The Laws: Nomos, 'The Ethical,' and the (Im)possibilities of Anarchia in Euripides's Iphigenia at Aulis." Arethusa 50 (2): 169-192. https://doi.org/10.1353/are.2017.0006

MACK, Joanna. "Child Maltreatment and Child Mortality." In Cooper and Whyte 2017, 85-93. https://doi.org/10.2307/j.cttlpv8988.11

McKenzIE, Lisa. 2015. Getting By. Estates, Class and Culture in Austerity Britain. Bristol, Chicago: Policy P. https://doi.org/10.2307/j.ctt1t8928t

Morwood, James. 2001. "A Note on the Euripus in Euripides' Iphigenia at Aulis." The Classical Quarterly 51.2: 607-608. https://doi.org/10.1093/cq/51.2.607

Osborne, Deirdre, ed. 2016. The Cambridge Companion to British Black and Asian Literature (1945-2010). Cambridge: Cambridge U.P. https://doi.org/10.1017/ CCO9781316488546

Owen, Gary. 2015. Iphigenia in Splott. London: Oberon Books. https://doi.org/10.50 40/9781350231337.00000005

Rebellato, Dan. 2015. "Enter the Greeks." Dan Rebellato. http://www.danrebellato. co.uk/spilledink/2015/7/5/enter-the-greeks [Accessed online on January 11, 2020].

SHERMAN Theatre. 2015. "Iphigenia in Splott." Sherman Theatre. https://www. shermantheatre.co.uk/performance/theatre/iphigenia-in-splott-tour/ [Accessed online on September 3, 2018]. 
SIERZ, Aleks. 2011. Rewriting the Nation: British Theatre Today. London: Methuen. https://doi.org/10.5040/9781408166819

—. 2014. In-Yer-Face Theatre: British Drama Today. London: Faber and Faber [eBook].

SMItH, Marc K. and Kraynak, Joe. Take the Mic. The Art of Performance Poetry, Slam, and the Spoken Word. Naperville, Illinois: Sourcebooks.

Sommers-Willet, Susan B. A. 2014. "From Slam to Def Poetry Jam: Spoken Word Poetry and its Counterpublics." Liminalities: A Journal of Performance Studies 10.3/4: 1-23. http://liminalities.net/10-3/spoken.pdf [Accessed online on January 18, 2020].

Sorum, Christina E. 1992. "Myth, Choice, and Meaning in Euripides' Iphigenia at Aulis." The American Journal of Philology 113.4: 527-542. https://doi. org/10.2307/295538

Trueman, Matt. 2016. "Iphigenial in Splott: Gary Owen's Protest Letter to a HardHearted State," The Guardian, January 28 2016, https:/www.theguardian.com/ stage/2016/jan/28/iphigenia-in-splott-gary-owen-interview-protest-letter-to-ahard-hearted-state [Accessed online on June 11, 2021].

Vaughan, Megan. 2016. "Blessed is He, who in the Name of Charity and Good Will, Shepherds the Weak through the Valley of Darkness." Synonyms for Churlish. http://synonymsforchurlish.tumblr.com/post/138249719228/blessed-is-hewho-in-the-name-of-charity-and-good [Accessed online on September 3, 2018]. 